\title{
Joint Publications Research Service Translations
}

\section{By RITA LUCAS and GEORGE CALDWELL}

DURING THE LAST SIX YEARS a large body of valuable research materials known as JPRS translations has become available to research libraries and to the general public. Much of this material is unique because the original sources are often completely unavailable to organizations outside the government. Furthermore, in the case of translations from difficult languages, such as Arabic and Chinese, it would be impossible for undergraduate and graduate students as well as for many scholars to make use of the original materials. Organizations distributing the translations have received many letters from scholars and librarians testifying to the great value of the materials. Theodore Kyriak of Research and Microfilm Publications, Inc., says of the period 19571961: "The JPRS social science translations represent over 90 per cent of all scholarly translations produced in English during that period in the social sciences." 1

The quantity of materials issuing from this source has been voluminous. By the end of 1962 , more than thirteen thousand and five hundred JPRS translations had been issued in the social sciences. Many thousands more had been issued in scientific and technical fields. Amounting to approximately one million pages since March 1957, about seven hundred thousand of which are in the social sciences, these materials now form one of the most complete and current collections of translations available in the United States. ${ }^{2}$

\footnotetext{
1 Theodore E, Kyriak, International Communist Developments, 1957-61, An index and guide to a collection of U.S. JPRS translations . . (Annapolis, Md. : Research \& Microfilm Publications, Inc., 1962), p. iv.

${ }^{2}$ Written information provided to the authors by T. W. Miller, Jr., Chief of JPRS, October 29, 1963.
}

Miss Lucas is Head, Documents Section, and $\mathrm{Mr}$. Caldwell is Head, Reference Department, University of Kansas Library.

Some research libraries have faced a bewildering dilemma in acquiring these translations because of the sheer volume of material, the variety of forms in which they are available, the multiplicity of sources, and the substantial costs involved. The purpose of this report is to assist libraries still struggling with the choice of which sets to purchase, by presenting as many of the facts as possible together with a comparison of advantages and disadvantages.

\section{HISTORY}

The Joint Publications Research Service (JPRS), a component of the Office of Technical Services, United States Department of Commerce, was established in 1957 at the initiative of a group of federal agencies which needed English-language translations of specific books, newspaper and periodical articles, and similar materials. Acting as the coordinator, the JPRS contracts with private individuals who have language and specialty competence to translate the materials sent to the JPRS. The early translations tended to be mostly scientific, but in time a greater proportion of materials in the social sciences was included. Also, in the early years the translations were available almost exclusively to the agencies which had requested them.

By 1958 some JPRS translations were being made available to the general public. The Monthly Catalog of U.S. Govern- 
ment Publications began listing and indexing the translations in the October 1958 issue, and these were then automatically reproduced by the Readex Corporation in its Microprint edition of U.S. government publications listed in the Monthly Catalog.

Also in 1958, the Office of Technical Services assumed responsibility for the distribution of all nonclassified government translations in science and technology and began selling Xerox copies of JPRS and other translations. OTS also began abstracting and indexing current translations (JPRS and other) for inclusion in the first edition of Technical Translations, volume I, number 1, January 2,1959 . OTS restricted itself to significant scientific and technical translations due to the sheer volume of other categories and to limitations of manpower. ${ }^{3}$

At the same time, the government publication's reading room of the Library of Congress began building a collection of JPRS reports and making photocopies of individual items available to the public from the library's photoduplication service.

In 1960 , as a result of increasing academic need for the social science translations, the Social Science Research Council obtained a subsidy from the National Science Foundation to distribute, at less than cost, paper copies of JPRS social science reports on Communist China to a group of libraries which had indicated interest during a nationwide survey. The following year, 1961, the American Council of Learned Societies obtained a similar grant to distribute the social science materials on East Europe and the USSR. These subsidized distribution programs were terminated July 1, 1962 , because of financial and other problems.

A new commercial firm, Research and Microfilm Publications, Inc. (RMP), was

$$
\text { Ibid. }
$$

then formed and began offering sets of JPRS social science reports on microfilm arranged by geographical area and subject. This new firm was also persuaded to distribute Xerox copies of the Chinese social science translations by subscription, but this program met with technical difficulties and was discontinued in February 1963.

The demise of the RMP China Xerox set, following the termination of the ACLS-SSRC program, left a significant void in the supply of full-size paper copies of JPRS social science reports available on a subscription basis. Libraries and individuals made numerous requests to JPRS for full-size processed copies. Heeding these requests, JPRS announced distribution programs ${ }^{4}$ which included availability of individual reports issued after February 1, 1963, as well as subscription services for social science reports issued after February 1963. In October 1963 subscription services were expanded to include scientific and technical reports, and all reports including those issued prior to 1963 were made available on a single-report basis.

At the present time, JPRS reports can be purchased from four sources: OTS (JPRS), Library of Congress, Readex Microprint Corporation, and Research and Microfilm Publications, Inc. (One other possibility is borrowing JPRS reports on interlibrary loan from the eight depository libraries for translations, which are listed in each issue of Technical Translations. However, these libraries receive the scientific and technical translations but not the social science reports.)

\section{BASES FOR DECISION}

Deciding where to buy individual translations or small sets is not much of a problem. The real difficulty comes in deciding on large sets of JPRS translations and where to buy them. Here, a library

\footnotetext{
4The actual sale of reports and subscription orders are handled by the Office of Technical Services, parent organization of JPRS.
} 
will have to consider a number of factors. Does it wish to have a complete set of permanent back files? Does it want the social science translations, the scientific and technical materials, or both? Does it want complete current coverage, or current reports only in specific subject fields likely to be used heavily by its clientele? How fast are current reports wanted? Will its patrons insist on full-size paper copy, or will they accept microfilm or microprint? Will the translations be kept together in a central location, or will it be necessary to send Chinese and Asian translations to a Asian collection, the USSR translations to a Slavic library, etc.? How much can the library afford to spend for the translations themselves, and for the personnel time necessary to service them?

\section{Present Sources}

Each of the four present sources seems to fill particular needs. A description of the services of each source follows. Much of the factual information has been outlined in the accompanying chart. Information has been obtained from publish-

\begin{tabular}{|c|c|c|c|c|c|}
\hline Source \& Form & Coverage & Arrangement & Access & Time Lag $^{1}$ & Price \\
\hline $\begin{array}{l}\text { Readex } \\
\text { Microprint } \\
\text { (microprint } \\
\text { cards) }\end{array}$ & $\begin{array}{l}\text { Every report } \\
\text { listed in } \\
\text { Monthly } \\
\text { Catalog } \\
1957-62: \\
80 \% \text { of total } \\
1962-63: \\
95 \% \text { of total } \\
\text { May 1963 } \\
\text { on: } 100 \%\end{array}$ & $\begin{array}{l}\text { By Monthly } \\
\text { Catalog entry } \\
\text { number }\end{array}$ & $\begin{array}{l}\text { Monthly } \\
\text { Catalog }\end{array}$ & 8 months & $\begin{array}{l}1 / 4-1 / 3 \& \text { page } \\
1957-62: \$ 1,375^{2} \\
1963: \$ 400^{2} \\
1964: \text { Unknown, } \\
\text { but increase } \\
\text { over } 1963^{3}\end{array}$ \\
\hline $\begin{array}{l}\text { Research \& } \\
\text { Microfilm } \\
\text { (microfilm } \\
\text { reels) . . . }\end{array}$ & $\begin{array}{l}\text { A. Social } \\
\text { Sciences: } \\
\text { complete } \\
\text { coverage } \\
\text { planned. }\end{array}$ & $\begin{array}{l}\text { Primarily } \\
\text { geographical } \\
\text { (Can be } \\
\text { purchased in } \\
\text { geographical } \\
\text { or } \\
\text { chronological } \\
\text { subdivisions) }\end{array}$ & $\begin{array}{l}\text { "Guides to } \\
\text { contents of } \\
\text { reels," some } \\
\text { indexes }\end{array}$ & 6-8 weeks & $\begin{array}{l}1 / 2 \& \text { per page } \\
1957-60: \$ 1,590, \\
\text { plus USSR } \\
1963: \$ 1,000^{4}\end{array}$ \\
\hline & $\begin{array}{l}\text { B. Sci. \& } \\
\text { technical: } \\
\text { All book- } \\
\text { length now, } \\
85-90 \% \\
\text { planned. }\end{array}$ & Subject & Currently in plar & nning stage & Unknown \\
\hline $\begin{array}{l}\text { Office of } \\
\text { Technical } \\
\text { Services (JPRS) } \\
\text { (processed or } \\
\text { Xerox copy). }\end{array}$ & $\begin{array}{r}\text { All JPRS } \\
\text { reports }\end{array}$ & $\begin{array}{c}\text { Individual } \\
\text { numbers }\end{array}$ & $\begin{array}{l}\text { Monthly } \\
\text { Catalog, } \\
\text { Technical } \\
\text { Translations }\end{array}$ & $1-3$ weeks & $\begin{array}{l}1 \text { f per page by } \\
\text { subscription; } \\
\text { individual } \\
\text { reports higher }\end{array}$ \\
\hline $\begin{array}{l}\text { Library of } \\
\text { Congress } \\
\text { (microfilm or } \\
\text { Xerox copy) }\end{array}$ & $\begin{array}{r}\text { All JPRS } \\
\text { reports }\end{array}$ & $\begin{array}{l}\text { Individual } \\
\text { reports or } \\
\text { several } \\
\text { numbers } \\
\text { ordered at } \\
\text { once to be } \\
\text { on same reel }\end{array}$ & $\begin{array}{l}\text { Monthly } \\
\text { Catalog, } \\
\text { Technical } \\
\text { Translations }\end{array}$ & \begin{tabular}{|l}
2 weeks \\
after \\
ordering
\end{tabular} & Varies \\
\hline
\end{tabular}

1 Time lag: figured from date of imprint of report to date received by subscribing library.

${ }^{2}$ Includes both social science and scientific and technical reports.

3 Amount uncertain. Estimate based on $1 / 4-1 / 3 \phi$ per page would put the cost for 1964 at $\$ 800$ to $\$ 1,000$. Past years' costs were underestimated by the company due to unpredictable output from JPRS.

Includes social science reports only. Cost of USSR set uncertain, but would probably add about $\$ 500$ when completed.

5ocial sciences only. 
er's brochures, through examining and using the materials, and through correspondence.

\section{READEX Microprint CORPORATION}

A fairly complete set of all JPRS translations, including both social science and scientific and technical reports, is available from Readex Microprint Corporation. The Readex set contains those JPRS reports listed in the Monthly Catalog of U.S. Government Publications as part of a regular program to reproduce all government publications listed in the Monthly Catalog. For the initial period of JPRS production, 1957 to May 1963, Monthly Catalog listing (and the Readex set) is 80 per cent complete, including 18,103 of the first 22,501 translations issued. ${ }^{5}$ Moreover, the Monthly Catalog did not begin listing JPRS translations until October 1958 , and a careful check shows a majority of the omissions are from the very earliest translations, for the most part those issued prior to January $1959 .^{6}$ Therefore, for translations of materials published after 1958 , i.e., anything issued in the last five years, or for the great bulk of the JPRS collection, the Monthly Cata$\log$ (and Readex set) is 90 per cent com-

\footnotetext{
5 Calculations were made for all Monthly Catalog listings prior to entry 8440 (JPRS 18,081) in the May 1963 issue, since after that point the listing of JPRS translations is complete, in numerical order, with no overlap, and with no pickup of earlier numbers. This avoids the possible distortions from using earlier points in the Monthly Catalog, such as missing earlier numbers picked up later, and not allowing for overlap of JPRS numbers in various issues. Before JPRS 18,081, according to Mr. Miller and Donald Wisdom, assistant head, government publications reading room, Library of Congress, JPRS production was: JPRS series (including $\mathbf{N}$ series), 18,080; N-L series, 1,204; DC series, 1,179; DC-L series, 2,038; over-all total, 22,501. Before JPRS 18,081, the Monthly Catalog lists 18,460 translations, of which 357 were R numbers, not a regular public series. This leaves 18,103 regular JPRS translations listed in the Monthly Catalog, which was 80 per cent of the 22,501 regular JPRS translations completed at that point.

Grom 1958-1963, the Monthly Catalog lists virtually none of the JPRS translations numbered DC1-275, NY1-607, and NYL 1-275. It also lacks 1300 of the first 1550 DC-L reports. Almost all the materials in these groups were dated 1958 or earlier. For the remaining 19,794 later reports prior to JPRS 18,081 the Monthly Catalog lacks only 1,941 reports, or 9.8 per cent, making the latter seven-eighths of the JPRS set 90.2 per cent complete.
}

plete. In addition, some omissions are reports which, though issued with standard JPRS numbers, were meant for "government use only" and were never available for public use, and thus as a rule were not listed in the Monthly Cata$\log .{ }^{7}$ Beginning with the July 1962 issue, the JPRS took special pains to assure the completeness of current and future Monthly Catalog listings, ${ }^{8}$ and as a result, the Monthly Catalog is 95 per cent complete for July 1962 through April $1963,^{\circ}$ and 100 per cent complete from May 1963 on. ${ }^{10}$

The Readex set is on microprint cards arranged by Monthly Catalog entry numbers, not JPRS numbers. Reports are arranged roughly in chronological order, although there are many exceptions and substantial overlapping of JPRS numbers between monthly issues. Each microprint card can contain a maximum of one hundred pages and often contains more than one report. Readex is now preparing a list which will indicate the Monthly Catalog entry number for each JPRS number. ${ }^{11}$

The chief attractions of the Readex set are its low cost and relative completeness, the minimum of space and effort required for shelving, the ease of pulling out individual reports from microprint cards as contrasted to reels of microfilm, the good quality of reproduction in the microprint process, and the close relationship between the Readex set and the Monthly Catalog, which provides a subject approach to the set. (Admittedly, much of the subject indexing is general and broad, rather than specific, since about 70 per cent of the JPRS material is grouped into serials, which the Monthly Catalog does

\footnotetext{
" Letter from T. W. Miller, Jr., to Rita Lucas, August 21, 1963.

${ }^{8}$ Letter from T. W. Miller, Jr., to George Caldwell, June 13, 1963.

Though planned and announced as complete, an actual count shows the Monthly Catalog listings omit 209 reports of the sequence JPRS 13,750-18,080.

10 From May-October 1963 the Monthly Catalog lists 2990 JPRS reports, the same number contained in its sequence JPRS 18,081-21,070.

11 Letter from G. William Bergquist, vice president, Readex Microprint Corporation, to Rita Lucas, September 30, 1963.
} 
not analyze for the most part. However, the serials are often specialized by subject and area, thereby providing a rough subject approach.)

There are several possible disadvantages of the Readex set. Heretofore, microprint has not been as easy to read as microfilm, a problem which some libraries may consider a serious drawback. Readers have been improving in recent years, and further improvements are promised, but how much better they will be remains to be seen. Also, there is no satisfactory means at present for making full-size copy from microprint. Readex does claim, however, to have a new reader-printer under development which will solve this problem. Other disadvantages are lack of flexibility, since the complete set has to be shelved in one location, and an eightmonth time lag between imprint date and date received at the library.

\section{RESEARCH AND MiCROFILM Publications, InCORPORATED}

Research and Microfilm Publications is a newcomer to the field. When the SSRC-ACLS projects were halted in July 1962, RMP began operation as a commercial firm to supply JPRS translations in the social sciences. The company says its coverage of current social science translations is complete. ${ }^{12}$ Back files were originally designed to complement the SSRC-ACLS distributions and were first issued for the 1957-60 period. However, coverage will now be extended up to July $1962 .{ }^{13}$ Back files for all areas except the USSR are now available for the period 1957-60, and some areas are complete through June 1962.

Recently the company announced plans to supply the scientific and technical translations. However, it does not intend complete coverage of this material, either past or current. Emphasis will be on serial

\footnotetext{
12 Letter from Theodore E. Kyriak, executive director, Research and Microfilms, Inc., to Rita Lucas, July 27, 1963.

${ }^{13}$ Letter from Theodore E. Kyriak to Rita Lueas, September 12, 1963.
}

and monograph items, omitting the ad hoc group (short, nonserial articles) unless there is "sufficient need for such service." 14 Back files of scientific and technical translations will be approximately 85-90 per cent complete. ${ }^{15}$

RMP film reels are not arranged by JPRS number but by the company's own rather complex geographic-subject arrangement. Current films are available in five geographic groupings: USSR, East Europe, China, Asia, and International Developments (the rest of the world). These five groups are then subdivided into three sections: serial, ad hoc, and book-length translations. Reports are grouped within these three sections by subject. Reels are issued either monthly or bimonthly. Back files are available in ten different geographic divisions, the five mentioned above plus Afghanistan, Indonesia, Mongolia, North Korea, and North Vietnam. With the exception of International Developments, the translations are grouped by subject areas such as press reports, sociology, politics, and economics. There are further divided by a third level according to form: books, serials, and ad hoc. Within each of these subdivisions, finally, the JPRS numbers appear in order.

This arrangement has the advantage of flexibility, since part of the set can be sent to branch or special libraries. Also it is useful for specialists who are interested in translations pertaining to one country or one aspect of a country. It is also possible to purchase only what is needed, such as translations applicable to only one country. Other advantages are the greater ease of reading microfilm as compared to microprint and the ability of current microfilm reader-printers to reproduce relatively good full-size paper copy from film for direct reading.

The disadvantages of the RPM microfilm set can be serious ones. A major

\footnotetext{
14 Letter from Theodore E. Kyriak to Rita Lucas, July 27,1963 .

${ }^{15}$ Ibid.
} 
problem is the complexity of the arrangement of the film reels, which make it quite difficult for a researcher or a librarian to find an individual JPRS translation. This is especially significant due to the lack of any comprehensive subject or numerical indexes for gaining access to the set. Various guides, bibliographies, subject indexes, and cross reference indexes are issued, but these do not seem to make the task of retrieval much easier, since most of them are about as complicated as the film sets themselves. Most back files have Guides to Contents which are more in the nature of inventories of the contents of each reel of film rather than numerical or subject indexes. Because of the large number of countries involved, International Developments back files have an index listing the page number of reports which contain information on specific countries. The cumulative indexes of report numbers issued since January 1963 are helpful but are complicated by a unique "information retrieval" code which necessitates further interpolation before the exact reel containing a specific report can be determined. Despite present shortcomings, however, bibliographic compilations and indexing efforts of RMP are commendable and improvements are being introduced.

Another major consideration with regard to the RMP set is the high cost, compared to microprint, if a library wants a complete set of all JPRS translations. Other disadvantages are the lack of completeness for scientific and technical translations, and the time elapsing between date of publication and the date a report is received by a subscribing library. In general, this source seems to be a compromise between the service offered by OTS and the edition published by Readex, both in terms of speed of delivery and cost.

Office of Technical Services (JPRS)

The United States Office of Technical Services, parent organization of JPRS, now sells all JPRS reports in full-size paper copy. Reports issued before February 1,1963 , must be ordered on an individual basis. Those issued after that date can be ordered either individually or on a subscription basis. The translations bought by subscription cost one cent per printed page; the cost of individual translations begins at one and one half cents per page for printed ${ }^{16}$ (stock) copy or ten cents for Xerox copy and decreases per page as the length of the report increases.

Subscriptions can be custom-tailored. An organization or individual can subscribe to any JPRS report series, to all of the ad hoc reports published in any or all of the specified subject categories (by geographic areas), or to any combination of these. Reports received on subscription arrive from several days to two weeks after imprint date.

Advantages of the JPRS set are the readability and preference of users for full-size copy, the speed with which the translations are received, the availability of single numbers, and the fact that small subscriptions tailored to individual needs can be obtained inexpensively, ranging in cost from sixty cents to several hundred dollars per year.

Accumulating at the rate of over two hundred thousand pages per year, these unbound copies have three very significant disadvantages as a comprehensive set: shelving problems, impermanence, ${ }^{17}$ and cost. For example, a complete set of current social science translations alone would cost $\$ 2000$ a year; a complete set (social sciences and scientific and technical sciences) would cost about $\$ 2700$ a year.

10 Written information from T. W. Miller, Jr., October $29,1963$.

${ }_{17} \mathrm{Mr}$. Kyriak, in a mimeographed announcement entitled "Addendum to the announcement of February 15,1963 , addressed to libraries participating in JPRS-SS-C (China) 1962-63 hard copy distribution project," contends that "due to the chemical properties of the paper, the mimeo copies should not be regarded as permanent records. According to archival and government standards, their life expectaney is limited to five years or less." Our own experience is that the JPRS mimeographed reports are beginning to deteriorate after two to three years. 


\section{LIBRARY OF CONGRESS}

The Library of Congress collection of JPRS reports is virtually complete. As of November 1963 it lacked only 136 of the first twenty-four thousand translations. ${ }^{18}$ At the present time, reports can be obtained from the Library of Congress photoduplication service on a single report basis only, in either of two forms, microfilm or Xerox copy. Theoretically, this limited service could be expanded, since the photoduplication service does the filming for both Readex and RMP projects and has all reports on hand. However, the Library of Congress has no definite plans for expansion of services at this time. ${ }^{19}$

\section{SUMMARY AND RECOMMENDATIONS}

Obtaining individual translations is no great problem. They can be purchased from OTS in processed paper copies (or Xerox copy if reports are out of stock), and they can be purchased from the Library of Congress in microfilm and Xerox copy. And, as mentioned earlier, the scientific and technical translations can be borrowed on interlibrary loan from the nearest of the eight regional depository libraries for translations.

Nor are small sets a problem. RMP offers some small back files on microfilm. Small current sets can be purchased from OTS or RMP, depending on whether the delivery of current paper copies, or slower delivery of more permanent film files, is desired.

The more difficult decisions arise when the library begins considering large sets. For large current sets, OTS is the only source for full-size paper copies. The RMP microfilm sets and the Readex microprint set are considerably less expensive, require less shelving space, and provide permanent files, but they are also considerably slower in arriving for current use, and are not as easy to read.

${ }^{18}$ Letter from Stephen R. Salmon, assistant chief, photoduplication service, Library of Congress, to Rita Lucas, November 14, 1963.

19 Ibid.
If a library wants comprehensive permanent back files, the choice narrows to the Readex microprint set versus the RMP microfilm set, since the OTS processed paper copies cannot be considered permanent. In our view, the Readex microprint set has the edge as an over-all back file. It is more complete at this point, easier to use, is better indexed, and much less expensive. Microprint readers are being improved, and obtaining full-size copy is not a serious problem. One library owning both the microprint and RMP microfilm sets reports the microprint set is used more often because of the greater ease of access. Although for the early years the microprint set is not as complete as the RMP microfilm set for the social sciences, it is more complete for the scientific and technical translations, and after May 1963 it is certainly as complete for the social sciences. If Readex would offer a complete set of the DC, DC-L, NY-L series, plus the NY series, numbers 1 through 607 , its over-all set would then be at least 95 per cent complete. ${ }^{20}$ If Readex could not be persuaded to make its set more complete by issuing these reports, a group of libraries could probably obtain a set of these early numbers on microfilm from Library of Congress at reasonable group rates.

However, if a library definitely wants to be as complete as possible in the social sciences, or wants a set it can break up and place in various locations, and is willing to cope with the less desirable arrangement and more difficult access, and can afford a higher price, it will probably choose the microfilm edition from $\mathrm{Re}$ search and Microfilm Publications, Inc. The value of this set would be greatly enhanced if the firm could develop a comprehensive, cumulative, easy-to-use subject and numerical index to the entire set, but financial obstacles seem to prevent such a project.

Other choices for a permanent back

${ }^{20}$ This would pick up 2,930 of the 4,398 reports missing from the Readex set. 
file are theoretically possible, if libraries are not satisfied with the existing sets. These would include comprehensive sets on microfilm or microfiche, arranged consecutively by JPRS number. A group purchase might make possible a reasonable price. Such a set would have the advantages of completeness, film's greater readability and reproducibility, and a simple arrangement for easy access. As another possibility, libraries might want to build permanent files of JPRS translations in microfilm or microprint and in addition obtain paper copies from OTS for temporary current use by subscribing to those series which would be most heavily used.

The availability of JPRS reports has changed many times since 1957 and, in fact, is still changing. Some libraries might want to press for alternate formats such as microfiche. However, the authors feel that the greatest need at the moment is for a more adequate comprehensive index to this body of research materials and that librarians might do well to urge the compilation of such an index. The Monthly Catalog lists all reports currently, but does not analyze them in the subject index of any the series, which comprise over 70 per cent of the reports. Technical Trans- lations gives adequate coverage to the more significant scientific and technical translations but does not touch the social science areas. A proposal by ACLSSSRC to the National Science Foundation asking for funds to sponsor a retrospective index of the social science material has not received a positive response.

Further information and details on prices can be obtained from the following:

T. W. Miller, Jr., Chief

Joint Publications Research Service

Office of Technical Services

U.S. Department of Commerce

Washington 25, D.C.

Photoduplication Service

Library of Congress

Washington 25, D.C.

G. William Bergquist, Vice President Readex Microprint Corporation

5 Union Square

New York 3, New York

Theodore E. Kyriak, Executive Director Research \& Microfilm Publications, Inc. Riva Road

Post Office Box 267

Annapolis, Maryland

\section{Appreciation}

The ACRL BOARD OF DIRECTORs, being aware of the great concern of college and university librarians regarding the publication of the statistics for their libraries, would be very pleased if these people would take the opportunity to show their appreciation individually to the U.S. Office of Education.

The following letter was sent to the Commissioner Francis Keppel, U.S. Office of Education, at the request of the ACRL Board of Directors:

\section{DEAR COMMISSIONER KePPEL:}

The Board of Directors of the Association of College and Research Libraries has asked me to express its appreciation to the U.S. Office of Education, Library Services Branch, for collecting and publishing the statistics for college and university libraries for $1962 / 63$, according to the prearranged schedule, by January 1964 .

The Board of this Association also expressed the hope that in future years this same publication schedule will be observed and that libraries and other agencies will cooperate with the U.S. Office of Education, Library Services Branch, in making an increasingly larger percentage of these statistics available. 